\title{
REGISTER BIDAN DI PUSKESMAS KECAMATAN SUNGAI TABUK KABUPATEN BANJAR
}

\section{Lita Luthfiyanti dan Isna Kasmilawati}

\section{Pendidikan Bahasa dan Sastra Indonesia STKIP PGRI Banjarmasin}

Jalan Sultan Adam, Komplek H. Iyus, No. 18 RT.23 Banjarmasin, Kalimantan Selatan. Kode pos 70121

email: litaluthfiya@stkipbjm.ac.id

\begin{abstract}
Abstrak
Register merupakan proses atau hasil dari pemakaian kosa kata khusus yang berkaitan dengan jenis pekerjaan maupun kelompok sosial tertentu, sehingga menunjukkan tipe proses sosial yang sedang terjadi. Register merupakan salah satu bentuk gejala variasi bahasa yang disebabkan oleh perbedaan bidang pemakaian dan memiliki ciri-ciri yang secara khusus menyertai atau menyatakan makna. Penggunaan bahasa register bidan ini tidak terlepas faktor situasi dan kondisi terutama yang menyangkut kapan dan dimana bahasa tersebut digunakan. Komunikasi dengan menggunakan bahasa register bidan ini dilakukan di lingkungan komunitas bidan tersebut baik di rumah sakit maupun di puskesmas Sungai Tabuk Kabupaten Banjar

Metode pengumpulan data ini dilakukan dengan mendeskripsikan data dalam fakta-fakta yang tampak sebagaimana adanya yang kemudian dianalisis. Tahap pengumpulan data primer yang berkaitan dengan bidan menggunakan teknik simak, cakap, dan catat. Adapun metode yang digunakan untuk menggali data primer adalah metode waawancara. Metode ini akan digunakan dengan bercakap-cakap atau mewawancarai informan utama yaitu bidan pembina secara langsung (tidak beraturan) untuk memperoleh data yang diperlukan.

Hasil penelitian ini meliputi [1] Bentuk penggunaan register register bidan. [2] Fungsi penggunaan register bidan di puskesmas Kecamatan Sungai Tabuk Kabupaten Banjar, di bedakan menjadi 3, yaitu (a) klasifikasi kelas kata; (b) frasa; dan (c) singkatan. [3] Faktor-faktor yang mempengaruhi penggunaan register bidan meliputi: (a) pembicara (partisipan) dan orang yang diajak bicara (persona); (b) sasaran dan isi pembicaraan; (c) sarana (ragam bahasa yang digunakan); dan (d) suasana dan setting pembicaraan.
\end{abstract}

Kata kunci: register, bidan

\section{Pendahuluan}

Sosiolinguistik berasal dari kata Sosio dan linguistik, sosio adalah masyarakat dan linguistik adalah kajian bahasa. Jadi Sosiolinguistik adalah kajian tentang bahasa yang dikaitkam dengan kondisi kemasyarakatan. Dalam studi sosiolinguistik variasi bahasa merupakan pokok bahasan, sehingga (Chaer dan Agustina, 2004:61) mendefinisikan sosiolinguistik sebagai cabang linguistik yang menjelaskan ciri-ciri variasi bahasa dan menetapkan korelasi ciri-ciri bahasa tersebut dengan ciri-ciri sosial kemasyarakatan.

Salah satu fungsi bahasa ialah sebagai alat komunikasi antara anggota masyarakat dan sebagai kontrol sosial. Bahasa sebagai fungsi alat komunikasi antara anggota masyarakat tersebut digunakan dalam berbagai lingkungan, tingkatan, dan kepentingan yang beraneka ragam dan 
kontrol sosial yang berfungsi mengendalikan komunikasi agar orang yang terlibat dalam komunikasi dapat saling memahami. Masing-masing mengamati ucapan, perilaku, dan simbolsimbol lain yang menunjukan arah komunikasi. Bahasa kontrol ini dapat diwujudkan dalam bentuk aturan misalnya; komunikasi ilmiah, komunikasi bisnis, komunikasi sosial, dan komunikasi kerja.

Sosiolinguistik merupakan ilmu antar disiplin antara sosiologi dan linguistik, dua bidang ilmu empiris yang mempunyai kaitan yang sangat erat. Sosiologi merupakan ilmu yang mempelajari tentang kegiatan sosial ataupun gejala sosial dalam suatu masyarakat.Sedangkan linguistik adalah bidang ilmu yang mempelajari bahasa, atau bidang ilmu yang mengambil objek bahasa sebagai objek kajiannya. Sosiolinguistik menurut Kridalaksana (2001) merupakan ilmu yang mempelajari ciri dan pelbagai variasi bahasa, serta hubungan di antara para bahasawan dengan ciri fungsi variasi bahasa itu di dalam suatu masyarakat bahasa.

Daya kreatif penutur bahasa memungkinkan suatu kelompok masyarakat menciptakan bahasa yang berbeda dari kelompok lain. Variasi disebabkan oleh perbedaan sosiologis. Dari berbagai macam bentuk variasi bahasa yang disebabkan oleh perbedaan sosiologis. Realisasi variasi sosial yang digunakan dalam penelitian ini adalah register yakni wujud variasi bahasa yang pemakaiannya terbatas atau secara khusus pada kelompok-kelompok sosial tertentu dan digunakan pada saat tertentu yang dietntukan oleh: apa yang anda kerjakan, dengan siapa dan dengan menggunakan sarana apa. Register menunjukkan tipe proses sosial yang sedang terjadi. Register merupakan merupakan salah satu bentuk gejala variasi bahasa yang disebabkan oleh perbedaan bidang pemakaian.

Register merupakan proses atau hasil dari pemakaian kosa kata khusus yang berkaitan dengan jenis pekerjaan maupun kelompok sosial tertentu. Menurut Adisumarto (1993:24) register adalah seperangkat (unit) makna penggunaan bahasa dengan makna dan tujuan yang relevan dengan fungsi bahasa secara khusus. Kekhususan tersebut meliputi kosakata terutama pemilihan katakata, penggunaan istilah-istilah dan idiom-idiom, ragam lisan atau tulisan serta pemilihan gaya wacana. Sedangkan menurut Suwito (1985: 25) register adalah bentuk variasi bahasa yang disebabkan sifat khas kebutuhan pemakainya. Register dengan kata lain bisa diartikan sebagai suatu bahasa yang biasa dipergunakan pada saat ini, bahasa yang tergantung pada apa saja yang dikerjakanya dan sifat kegiatanya mencerminkan aspek lain dari tingkat sosial yang biasanya melibatkan masyarakat tertentu. Register muncul disebabkan oleh banyak hal kebahasaan, salah satunya variasi bahasa.

Dari beberapa pendapat di atas dapat disimpulkan bahwa register adalah pemakaian bahasa yang terkait dengan kelompok kerja atau sosial tertentu yang digunakan dalam situasi (medan, pelibat, sarana) yang terkait dengan kelompok tersebut. Register memiliki ciri-ciri yang secara khusus menyertai atau menyatakan makna. Ciri itu, antara lain leksikogramatis, penanda fonologis yang memiliki fungsi untuk memberi tanda register yang dimaksud, ciri penunjuk berupa bentuk 
kata tertentu, pemilihan pola sintaksis dan retorika khusus, penanda gramatis tertentu, penggunaan istilah dan idiom, dan pemilihan gaya bahasa.

Profesi bidan secara nasional diakui di dalam undang-undang pemerintahan Indonesia. Bidan merupakan salah satu tenaga pelayanan kesehatan professional dan secara internasional diakui oleh International Confederation of Midwives (ICM), International Federation of Gynecology and Obstetrics (FIGO) dan World Health Organization (WHO). Memilki sifat bertanggung jawab dan akuntabel, yang bekerja sebagai mitra perempuan untuk memberikan dukungan, asuhan, dan nasehat selama masa hamil sampai masa persalinan dan masa nifas. Bidan memimpin persalinan atas tanggung jawab sendiri dan memberikan asuhan kepada bayi baru lahir. Asuhan ini mencakup upaya pencegahan, promosi persalinan normal, deteksi komplikasi pada ibu dan anak, dan akses bantuan medis atau bantuan lain yang sesuai, serta melaksanakan tindakan kegawat daruratan.

Bidan mempunyai tugas penting dalam proses persalinan. Ketika menolong pasien bidan menggunakan bahasa medisnya dengan mitra tuturnya untuk melakukan tindakan antenatal dan persiapan menjadi orang tua serta dapat meluas pada kesehatan perempuan, kesehatan seksual atau kesehatan reproduksi dan asuhan anak. Bidan dapat praktik di berbagai tatanan pelayanan, mulai dari Puskesmas, Rumah Sakit hingga membuka praktik di rumahnya. Dalam perkembangannya tersebut, praktik komunikasi antar sesama profesi bidan mulai berkembang, bidan memiliki istilah komunikasi sendiri yang berbeda dengan profesi lainnya seperti jurnalis, militer, perawat, maupun dokter. Bidan sebagai masyarakat tutur yang besar dan beragam memperoleh kemampuan berkomunikasi yang dimiliki dari hasil satu interaksi komunikasi secara langsung dengan menggunakan berbagai bahasa atau variasi bahasa yang ada. Keberadaan bahasa atau variasi ikut mempengaruhi dalam pemilihan dan penggunaan bahasa para bidan ketika melakukan percakapan dengan mitra tuturnya. Kondisi inilah yang dapat mengakibatkan terjadinya sebuah peristiwa kebahasaan yakni variasi bahasa jargon.

Puskesmas Kecamatan Sungai Tabuk adalah puskesmas yang berada di Desa Sungai Tabuk Keramat. Puskesmas ini melayani masyarakat yang tinggal di desa-desa di Kecamatan Sungai Tabuk selama 24 jam. Dokter, perawat dan bidan secara bergantian jaga di puskesmas, sehingga pelayanan terhadap masyarakat dapat berjalan dengan maksimal. Beberapa ruangan juga dipersiapkan untuk memudahkan masyarakat yang memerlukan pelayanan, seperti ruang UGD, rawat inap, ruang bersalin, dan sebagainya. Di setiap desa sebenarnya sudah ditunjuk satu orang bidan. Namun, ketika ada ibu hamil yang akan melahirkan, bidan tidak boleh datang ke rumah pasien. Pasien harus ke puskesmas, karena di puskesmas alat-alat lebih lengkap, sehingga diharapkan pertolongan terhadap pasien dapat dilakukan dengan lebih baik.

Landasan teori yang digunakan ada dua teori SPEAKING Hymes dan pembentukan istilah Kridalaksana. Teori Speaking Menurut Hymes, dalam proses komunikasi dengan menggunakan 
suatu bahasa, seseorang membutuhkan lebih dari sekedar kemampuan untuk menggunakan bahasa sesuai dengan aturan-aturan tata bahasa. Penggunaan bahasa haruslah sesuai dengan konteks, yakni hal-hal yang menjadi ruang lingkup serta mempengaruhi penggunaan bahasa itu sendiri. Hymes merumuskan aspek-aspek yang mempengaruhi penggunaan bahasa dalam "Dell Hymes Model of Speaking". Dalam teorinya, Hymes menjelaskan bahwa untuk berbahasa dengan benar, seseorang tidak hanya mempelajari kata-kata serta aturan-aturan tata bahasa, tapi juga konteks dari penggunaan tata bahasa tersebut.

Bentuk istilah ke khasan kosakata merupakan dasar penggolongan suatu register. Bentuk istilah tersebut terbentuk oleh kosakata yang mempunyai makna tersendiri. Bentuk yaitu penampakan atau rupa satuan bahasa dan penampakan satuan gramatikal atau leksikal yang dipandang secara fonis atau grafemis (Kridalaksana, 2007:32). Batasan dari bentuk ini hanya berupa satuan gramatikal atau leksikal.Istilah merupakan kata atau gabungan kata yang dengan cermat mengungkapkan konsep, proses, keadaan, sifat yang khas dalam bidang tertentu (Kridalaksana, 2007:97). Bentuk kata dapat berupa sebagai bentuk tunggal maupun bentuk kompleks. Kata merupakan satuan bebas yang paling kecil, atau dengan kata lain, setiap satuan bebas merupakan kata. Masing-masing istilah register bentuk kata akan diuraikan sebagai berikut.

\section{Metode}

Metode pengumpulan data ini dilakukan dengan menempuh data dari seluruh tuturan percakapan yang dipandang representatif. Pengumpulan data percakapan yang memenuhi kriteria peristiwa penggunaan bahasa register yang akan dirasa cukup ditunjukan pola yang telah di identifikasi. Tahap pengumpulan data primer yang akan berkaitan dengan bidan menggunakan teknik simak, cakap, dan catat. Adapun metode yang digunakan untuk menggali data primer adalah metode waawancara. Metode ini akan digunakan dengan bercakap-cakap atau mewawancarai informan utama yaitu bidan pembina secara langsung (tidak beraturan) untuk memperoleh data yang diperlukan.

\section{Hasil dan Pembahasan}

Dalam penelitian jurnal ilmiah ini berupa bentuk percakapan bidan di klinik dan rumah bersalin delta mutiara, yang jika dianalisis memiliki unsur bentuk kata, frasa, dan abreviasi. Serta di temukannya faktor dan fungsi register bidan di Sungai Tabuk Kabupaten Banjar. Bidan dan para medis di puskesmas Sungai Tabuk Kabupaten Banjar menggunakan bahasa medis kebidanan yang memiliki ciri khas bentuk penggunaan bahasanya, dengan sebuah bentuk kerjasama setiap anggota tim medis bidan. Kekompakan berbahasa yang terlihat terkadang hanya dikenal oleh anggota tim 
medis bidan rumah bersalin delta mutiara yang terjun dalam proses persalinan. Berikut bentuk, fungsi, dan faktor register profesi bidan yang sudah dianalisis datanya:

1. Bentuk Penggunaan Register Register bidan,

Register bidan di rumah puskesmas Sungai Tabuk Kabupaten Banjar ini sudah menerapkan penggunaan bahasa medis kebidanan yang memiliki ciri khas bentuk penggunaan bahasanya, dengan sebuah bentuk kerjasama setiap anggota tim medis. Kekompakan berbahasa yang terlihat terkadang hanya dikenal oleh anggota tim medis bidan di puskesmas Sungai Tabuk Kabupaten Banjar yang terjun dalam proses persalinan. Berikut bentuk konteks percakapannya yang terdapat tiga bentuk register yaitu kata, frasa, singkatan.

Bidan : G3 Masuk inpartu kala 1 fase laten, empat jam lagi tolong di VT.

Para Medis : Siap Bu.

Bidan : Tolong dilihat lagi VT dan CHPBK.

Para Medis : Baik, Hasil VT pembukaan 5. Masuk kala 1, fase aktif, ketuban positif, molase (penumpukan tulang kepala) negatif, cortonen positif hasilnya 140, penurunan kepala DJJ, H.II, evicement 50\% panggul normal.

Proses komunikasi diatas tersebut antara bidan (Senior) dan para medis (tim bidan) mneggunakan narasi yang cepat dan intonasi yang tegas dan lugas. Bentuk bentuk istilah singkatan, kata, dan frasa penggunaan register bidan ini terdapat isitlah asing di dalamnya, meskipun ada juga yang menggunakan sedikit istilah register bahasa indonesia namun dalam bentuk abreviasi singkatan.

\begin{tabular}{|c|c|c|}
\hline Singkatan & Kepanjangan & Arti Kata \\
\hline G3 & Grafida 3 & Kehamilan ke-3 \\
\hline VT & Vaginal Toucher/ Vaginal Tousse & $\begin{array}{l}\text { Memasukkan tangan ke dalam jalan lahir ibu } \\
\text { bersalin untuk memantau perkembangan proses } \\
\text { persalinan atau lazim disebut periksa dalam dan } \\
\text { sejenisnya. perlu pengetahuan, keterampilan, } \\
\text { pengalaman, tetapi juga butuh perasaan. } \\
\text { Pengecekan detak nadi jantung pada janin. }\end{array}$ \\
\hline DJJ & Detak Jantung Janin & Cortonen adalah detak jantung janin. \\
\hline CHPBK & Cortonen His Penurunan Bandle Ketuban & $\begin{array}{l}\text { Ukuran-Ukuran Panggul posisi ke } 2 \text {. Pengukuran } \\
\text { panggul kecil dapat diperiksa secara klinis dengan } \\
\text { melakukan pemeriksaan dalam. }\end{array}$ \\
\hline H.II & Hodge ke 2 & \\
\hline
\end{tabular}

Seperti yang sudah di jelaskan sebelumnya bahawa percakapan diatas juga terdapat istilah bentuk kata asing dan frasa asing yang memiliki sebuah arti tertentu. Berikut kata asing register yang terdapat dalam konteks percakapan tersebut:

1. Kata Hodge $\rightarrow$ berasal dari bahasa latin yang berarti ukuran-ukuran Panggul. Pengukuran panggul kecil dapat diperiksa secara klinis dengan melakukan pemeriksaan dalam ataupun dengan rontgenologi. 
2. Kata Kala $\rightarrow$ berasal dari bahasa sansekerta yang berarti waktu a) Kala $I=$ Waktu untuk pembukaan serviks sampai manjadi pembukaan lengkap $10 \mathrm{~cm}$. b) Kala II = Waktu untuk pengeluaran. Pada kala ini, berkat kekuatan his dan kekuatan mengedan, janin di dorong keluar sampai lahir. c) Kala III = Waktu uri/ plasenta. Pada kala ini, plasenta terlepas dari dinding uterus/ rahim dan dilahirkan. d) Kala IV = Mulai dari lahirnya plasenta dan lamanya 1 jam. Pada kala ini diobservasi adanya perdarahan postpartum atau tidak.

3. Kata Fase $\rightarrow$ berasal dari bahasa belanda, yang awalnya dari bahasa yunani yang berarti Tahap, stadium, tingkatan, jangka.

a. Frasa Fase Laten = Dimana pembukaan serviks berlangsung lambat sampai pembukaan $3 \mathrm{~cm}$ berlangsung dam 7 sampai 8 jam.

b. Frasa Fase Aktif = Berlangsung 6 jam dan dibagi atas 3 sub fase yaitu:

1) Frasa Fase Akseksasi: Berlangsung 2 jam. Pembukaan menjadi $4 \mathrm{~cm}$.

2) Frasa Fase Dilatasi maksimal (steady): Berlangsung 2 jam, pembukaan cepat menjadi 9 $\mathrm{cm}$.

3) Frasa Fase deselarasi: Berlangsung lambat, dalam waktu 2 jam pembukaan menjadi 10 $\mathrm{cm}$ atau lengkap.

Berikut bentuk frasa asing register yang terdapat dalam konteks percakapan tersebut.

1. Frasa In partu $\rightarrow$ gabungan dua kata dari kata in dan partu. In berasal dari bahasa inggris yang berarti masuk dan partu atau partus berasal dari bahasa latin, yang berarti suatu tindakan proses persalinan. Jadi in partu adalah wanita yang sedang masuk dalam keadaan proses persalinan. Kondisi tersebut menjelaskan bahwa pasien sudah mengalami pembukaan dengan cepat dan proses persalinan mulai berangsung. Dengan tahapan-tahapan fase yang berjalan dengan cepat. Kondisi percakapan tersebut antar sesama bidan yang saling menggunakan bahasa register, yakni dengan kata asing, frasa asing, dan singkatan. Dari beberapa bentuk percakpan yang ada percakpan di bawah ini terdapat bentuk register singkatan pada proses jenis pemeriksaan dalam dan luar.

a. Bentuk Pemeriksaan Luar

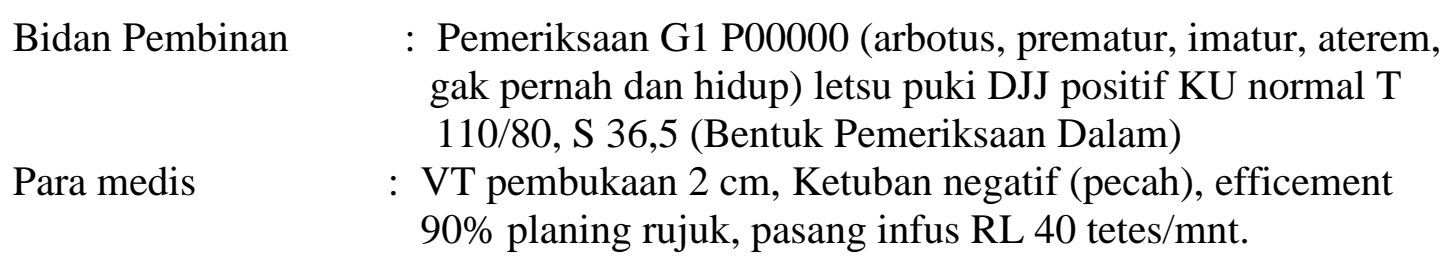


Dalam proses komunikasi diatas tersebut dapat di jabarakan bentuk istilah penggunaan register dalam tebel 2 di bawah ini.

\begin{tabular}{|l|l|l|}
\hline \multicolumn{1}{|c|}{ Singkatan } & \multicolumn{1}{c|}{ Kepanjangan } & \multicolumn{1}{c|}{ Arti Kata } \\
\hline G1 & Grafida 1 & Kehamilan Pertama \\
\hline DJJ & Detak Jantung Janin & Pengecekan detak nadi jantung pada janin \\
\hline P00000 & & $\begin{array}{l}\text { Perencanaan tindakan bahwa pasien arbotus, prematur, } \\
\text { imatur, aterem gak pernah dan hidup Digunakan untuk } \\
\text { menjelaskan kondisi kedaaan pasien secara umum (ibu dan } \\
\text { anaknya). }\end{array}$ \\
\hline KU & Keadaan Umum & $\begin{array}{l}\text { Larutan steril dari Kalsium klorida, Kalium klorida, } \\
\text { Natrium klorida dan Natrium laktat dalam Air untuk injeks. }\end{array}$ \\
\hline RL & Ringer Laktat & Pengukuran tekanan darah. \\
\hline T & Tensi & \\
\hline
\end{tabular}

Kondisi pada kasus tersebut menjelaskan bahwa pasien sudah mengalami pembukaan dan ketuban sudah mulai pecah sehingga perlu di rujuk ke rumah sakit. percakapan antar sesama bidan itu menggunakan bahasa register, yakni dengan kata asing dan frasa yang disingkat dengan di bedakannya penggunaan pada pemeriksaan. Setiap bahasa sebenarnya mempunyai ketetapan atau kesamaan dalam hal tata bunyi, tata bentuk, tata kata, tata kalimat, dan tata makna, akan tetapi karena adanya beberapa faktor yang terdapat dalam suatu masyarakat antara lain: usia, pendidikan, agama, bidang kegiatan, profesi, dan latar belakang budaya daerah, maka bahasa itu menjadi beragam.

Terjadinya keragaman atau kevariasian bahasa ini bukan hanya disebabkan oleh penuturnya yang tidak homogen, tetapi juga karena kegiatan interaksi sosial yang mereka lakukan sangat beragam. Setiap kegiatan memerlukan atau menyebabkan terjadinya keragaman bahasa.

\section{Fungsi Penggunaan Register Bidan di puskesmas Kecamatan Sungai Tabuk Kabupaten Banjar}

Bahasa register bagi penggunaannya mempunyai fungsi umum sebagai media komunikasi diantara pembicaraan tersebut. Demikian pula dengan bahasa register bidan yang digunakan dalam proses persalinan. Secara umum fungsi bahasa register adalah (1) untuk memberi serta memperkokoh identitas komunitas kelompok pengguna tersebut; (2) untuk melindungi komunitas kelompok pemilik bahasa register tersebut dari ancaman kolektif lain atau penguasa; (3) untuk memperkokoh kedudukan komunitas kelompok pada jenjang pelapisan masyarakat; dan (4) untuk memperkokoh kepercayaan komunitas kelompok pengguna.

Pembentukan istilah kata, frasa, abreviasi berupa singkatan dan akronim tersebut biasanya digunakan sebagai fungsi agar profesi sesama bidan dapat mudah terjalin cepat serta memperkokoh identitas profesi bidan penggunaanya, terutama bagi orang baru. Seperti mahasiswa yang sedang melakukan praktik di tempat klinik dan rumah bersalin delta mutiara sukodono sidoarjo agar mahasiswa yang praktik tersebut dapat mudah menghafalkan kosa kata yang terlalu panjang. 
Contohnya pada bentuk frasa, bidan lebih sering menggunakan istilah berupa singkatan dan akronim di bandingkan bentuk frasa yang terlalu panjang karena akan sulit untuk di hafalkan. Contoh bentuk frasa "tinggi fundus uterus" yang akhirnya menjadi singkatan TFU dalam percakpan terebut.

Dalam proses pembentukan istilah bahasa register bidan, profesi bidan juga memiliki fungsi sebagai pelindung untuk melindungi sesama bidan tersebut. Agar komunikasi tersebut tetap lancar dan tidak ada orang yang bukan ahli (profesi bidan) tersebut menyalahgunakan sebagai mal praktik bahasa yang salah dan akhirnya dapat merugikan pasien maupun lawan tuturnya. Dengan adanya bahasa register bidan, kini profesi bidan memiliki fungsi bahasa register sendiri untuk memperkokoh kedudukan komunitasnya di dunia medis maupun kelompok pada jenjang pelapisan masyarakat. Pada jaman dahulu bidan belum diakui oleh lapisan masyarakat maupun dalam dunia medis, karena masih dianggap perdukunan dan tak logis ilmunya, namun saat ini sudah diakui oleh lapisan masyarakat dan juga diakui di dunia medis secara international sehingga ada istilah bahasa yang hampir sama dengan dunia medis kedokteran.

Selain fungsi-fungsi register di atas fungsi register bidan ini berfungsi untuk memperkokoh kepercayaan antar sesama profesi bidan. Penutur dan petutur pengguna bahasa register bidan berfungsi agar dapat terjamin secara keselarasan kerja sama untuk melakukan suatu tindakan persalinan, karena jika tidak saling mempercayai akan terjadi masalah terhadap pasien. Contoh pada percakapan data primer di bawah ini.

Bidan Junior : KU normal, ibu boleh pulang, motivasi mobilisasi bertahap.

Bidan Senior : Ingatkan nutrisi ASI tiap 2 jam atau sesering mungkin, jemur bayi tiap jam 7

Bidan Junior : Siap.

pagi, 1 minggu lagi imunisasi HB.

Percakapan di atas menunjukkan kekompakan dan saling mempercayai antara bidan senior dan bidan junior yang menggunakan bahasa register. Tidak ada keraguan dalam berkomunikasi untuk memberikan asupan informasi kepada pasien. Fungsi bahasa register bidan di puskesmas Sungai Tabuk Kabupaten Banjar tidak dimaksudkan agar pasien tidak mengerti, namun tujuannya adalah keseragaman, universalitas. Agar istilah yang dituliskan dokter maupun bidan di Indonesia tetap dapat dipahami dokter ataupun bidan di negara lain. Fungsi lain bahasa register bidan ini adalah agar tidak ada penyalahgunaan kesalahan dalam berkomunikasi untuk membuat resep obat ataupun ketika melakukan tindakan operasi dan konsultasi baik secara lisan maupun tulisan.

3. Faktor-faktor yang Mempengaruhi Penggunaan Register Bidan

Dalam proses komunikasi (penggunaan berbahasa) terdapat beberapa komponen yang saling terkait satu sama lain untuk menunjang keberhasilan komunikasi. Komponen-komponen tersebut meliputi: (1) pembicara (partisipan) dan orang yang diajak bicara (persona); (2) sasaran dan isi pembicaraan; (3) sarana (ragam bahasa yang digunakan); dan (4) suasana dan setting pembicaraan. 


\section{1) Partisipan dan Persona}

Rata-rata penutur dan petutur penggunan istilah medis kebidanan adalah kalangan wanita atau orang dewasa. Bidan di puskesmas Sungai Tabuk Kabupaten Banjar adalah salah satu komunitas yang memiliki profesi yang sama di bidangnya ketika berkomunikasi baik dari mahasiswa yang sedang praktik maupun bidan pegawai yang sudah bekerja disana. Permasalahan partisipan dan persona meliputi usia, gender dan relasi. Penggunaan bahasa register sehubungan dengan pihakpihak yang terlibat dalam peristiwa komunikasi dijabarkan di bawah ini.

a. Usia

Norma-norma penggunaan bahasa register juga melibatkan usia. Mengingat kelompokkelompok masyarakat dapat terbentuk karena faktor usia. Munculnya variasi bahasa bagi kelompok tersebut juga bisa ditentukan oleh usia. Kelompok usia ini akhirnya membatasi ruang gerak atau mampu mengatur perilaku berbahasa masayarakat penuturnya Penggunaan bahasa register bidan ini secara langsung memiliki batasan usia.

b. Gender

Bahasa penggunaan register ini lebih banyak tersebar di kaum wanita yang memiliki profesi bidan. Hal ini karena di Indonesia tidak ada bidan berjenis laki-laki kecuali dokter spesialis obgin atau kandungan. Dengan demikian, kemungkinan di pergunakan bahasa register ini lebih besar pada kaum wanita atau ibu-ibu yang memiliki prof esi bidan daripada kaum lelaki atau bapak-bapak.

c. Relasi

Hubungan diantara penutur-penutur bahasa register bidan ini juga mempunyai pengaruh tersendiri. Hubungan yang akrab antar sesama profesi dapat terjalin meskipun memiliki perbedaan status jabatan antara senior dan junior. Hubungan yang akrab antara bidan senior dengan junior tidak hanya saat mereka bekerja saat menolong pasien sebagai bidan. namun ketika di luar pekrjaan mereka juga akrab. Komunikasi yang terjalin juga tidak hanya pada satu tempat melainkan di waktu dan tempat yang berbeda misalkan, padawaktu jam istirahat di kantin mereka juga memungkinkan adanya obrolan seputar permasalahan pasien dengan menggunakan istilah bahasa medis tersebut.

\section{Sasaran dan Isi Pembicaraan}

a. Tujuan dan Sasaran

Tujuan seseorang melakukan komunikasi dengan orang lain adalah untuk menyampaikan pesan-pesan melalui kode-kode bahasa. Suatu pembicaraan atau komunikasi dapat bersifat rahasia (tertutup) dan dapat pula bersifat terbuka. Demikian juga dengan tujuan pembicaraan dengan menggunakan bahasa register bidan di puskesmas Sungai Tabuk Kabupaten Banjar.

Bahasa register bidan ini merupakan salah satu bentuk bahasa medis kebidanan yang diciptakan agar komunitas kelompok berprofesi kebidanan ini dapat secara leluasa berkomunikasi dengan kelompok komunitasnya. Segala bentuk dan makna yang muncul karena 
adanya kesepakatan para penuturnya. Kode-kode bahasa yang unik dan ada kalanya tidak lazim digunakan dalam masyarakat umum menjadi seperangkat bahasa yang dapat digunakan sebagai alat komunikasi oleh sekelompok orang yang berada dikominitasnya.

Bentuk-bentuk bahasa yang unik tersebut digunakan dengan maksud merahasiakan isi pembicaraan dari pihak luar agar tidak adanya penyalahgunaan bahasa medis tersebut. Apabila ada pihak luar yang mengetahuinya ditakutkan penggunaan bahasa tersebut dalam proses kominukasi akan mengalami kesulitan atau misskomunikation, misalanya: ketika apa yang dimaksud tidak sama apa yang diinginkan dan dapat menibulkan kesalahpahaman ketika berkomunikasi bagi orang awam yang mencoba menggunakannya. Yang menjadi sasaran pembicaraan dalam penggunaan bahasa register bidan ini adalah komunitas sesama profesi bidan ataupun yang memiliki kesamaan bahasa medis (dokter obgin).

b. Isi pembicaraan

Isi pembicaraan dalam kelompok ini bukan hanya membicraakan permasalahan kondisi pasien baik ketika proses persalinan hingga konsultasi. Topik-topik yang ringan seputar kegiatan sehari-hari juga turut dibicarakan dalam komunitas ini. Topik menganai ibu hamil muda. Topik masalah pertumbuhan anak, topik menganai seputar permasalahan seorang kaum wanita. Topik tersebut dibicarakan dengan menggunakan bahasa register bidan, agar tidak ada yang mengetahui maksud selain penutur dan petutur.

\section{Sarana Pembicaraan}

Komunitas bidan dalam berkomunikasi dengan sesamanya tidak saja menggunakan ragam bahasa baku (ragam bahasa pada umumnya) seperti bahasa indonesia ataupun bahasa daerah. Namun juga menggunakan bahasa ragam bahasa yang tidak baku yakni bahasa register bidan. Bahasa register bidan umumnya digunkan dalam pembicaraan (komunikasi) yang melibatkan secara langsung penutur dan pertuturannya. Kedua belah pihak yang terlibat komunikasi tersebut saling bertatap muka (komukiasi langsung). Sedangkan pembicaraan yang bersifat tidak langsung seperti melalui telepon selular.

a. Setting (Suasana dan situasi) Pembicaraan

Penggunaan bahasa register bidan ini tidak terlepas faktor situasi dan kondisi terutama yang menyangkut kapan dan dimana bahasa tersebut digunakan. Komunikasi dengan menggunakan bahasa register bidan ini dilakukan di lingkungan komunitas bidan tersebut baik di rumah sakit maupun di puskesmas Sungai Tabuk Kabupaten Banjar. Namun juga tidak dipungkiri bahwa penggunaan bahasa register bidan ini bisa digunakan diluar ruang kerja tersebut.

Situasi dan suasana berpengaruh dalam menggunakan bahasa register bidan ini. Situasi yang nyaman dan mendukung akan mempeacar komunikasi mereka namun sebaliknya, mereka akan menggunaakan bahasa register dengan berhati-hati jika dirasa situasinya tidak mendukung 
kelancaran komunikasi. Situasi yang mendukung kelancaran komunikasi adalah dimana saat mereka berkumpul dalam satu kelompok yang sama seperti pada waktu proses persalinan di klinik dan rumah bersalin delta mutiara sidoarjo atau tempat rumah sakit lainnya. Sebaliknya situasi yang tidak mendukung adalah di tempat keramaian atau di luar ruangan dan bukan berada dalam satu kelompok. Jika hal itu terjadi maka, penggunaan bahasa register bidan ini digunakan dengan maksud agar komunikasi mereka tidak diketahui secara mudah oleh masyarakat umum. Tentunya hanya mereka saja yang mengetahui maksud dari bahasa register bidan yang digunakan.

\section{Simpulan}

Register adalah variasi bahasa yang ditinjau dari segi pemakaiannya atau fungsinya. Register merupakan pemakaian kosakata khusus yang berkaitan dengan jenis pekerjaan pekerjaan maupun kelompok sosiala tertentu. Jadi register berkaitan erat dengan variasi bahasa berkenaan dengan pemakaiannya atau fungsinya, yakni pekerjaan seseorang. Bentuk register bidan di puskesmas Sungai Tabuk kabupaten sebagai berikut.

1. Bentuk Register bidan yang di bedakan menjadi 3, yaitu klasifikasi kelas kata, frasa, dan singkatan.

a. Bentuk klasifikasi kelas kata merupakan bahasa asing yang berasal dari bahasa Latin, Yunani, Inggris, dan Belanda. Namun sebagian besar berasal dari bahasa Latin, Yunani, karena sebagian besar bahasa medis (kedoteran maupun kebidanan) tertua khususnya berasal dari italia.

b. Bentuk frasa merupakan bahasa asing yang berasal dari bahasa latin yunani, inggris, dan Belanda. Namun sebagian besar berasal dari bahasa Latin, Yunani, karena sebagian besar bahasa medis (kedoteran maupun kebidanan) tertua khususnya berasal dari italia.

c. Abreviasi secara sederhana merupakan proses morfologis berupa pemenggalan satu atau beberapa bagian dari kombinasi sebuah huruf atau sekumpulan huruf sebagai bentuk pendek dari sebuah atau beberapa kata. Penyingkatan bisa dilakukan terhadap sebuah kata ataupun sebagai terhadap beberapa kata. Jenis singkatan dibagi menjadi dua bentuk, yaitu (1) Bentuk Akronim dan (2) Bentuk singkatan. Bentuk singkatan dan akronim tersebut digunakan perckapan sesama bidan untuk pasien dalam kondisi situasi proses pemeriksaan luar dan pemeriksaan dalam.

2. Register bidan puskesmas Sungai Tabuk Kabupaten Banjar mempunyai fungsi umum sebagai media komunikasi di antara penggunaannya. Demikian pula dengan bahasa register yang digunakan dalam proses persalinan. Secara umum fungsi bahasa register adalah (1) untuk memberi serta memperkokoh identitas komunitas kelompok pengguna tersebut; (2) untuk melindungi komunitas kelompok pemilik bahasa register tersebut dari ancaman kolektif lain atau 
penguasa; (3) untuk memperkokoh kedudukan komunitas kelompok pada jenjang pelapisan masyarakat; dan (4) untuk memperkokoh kepercayaan komunitas kelompok pengguna.

3. Faktor-faktor yang mempengaruhi register bidan di puskesmas Sungai Tabuk Kabupaten Banjar berhubungan dengan komponen-komponen dalam proses komunikasi. Komponen-komponen tersebut meliputi: (1) pembicara (partisipan) dan orang yang diajak bicara (persona); (2) sasaran dan isi pembicaraan; (3) sarana (ragam bahasa yang digunakan); dan (4) suasana dan setting pembicaraan.

\section{Daftar Pustaka}

Adisumarto, M. 1993. Pengantar Sosiolinguistik. Yogyakarta: FPBS IKIP Yogyakarta.

Chaer, Abdul dan Agustina. 2004. Sosiolinguistik: Perkenalan Awal. Jakarta: PT. Rineka Cipta. 2007. Linguistik Umum. Jakarta: Rineka Cipta.

Chomsky, N.A. 1965. Aspects of the Theory of the Syntax. Cambridge: MIT Press.

Fishman, Joshua. 1968. Sociallinguistic: A Brief Introduction. Massachuse HS: Newbury House Publisher.

Hymes, Dell H. 1972. "The Ethnography of Speaking”, dalam Reading in the Sociology of Language, edited by Joshua A. Fishman. Paris: Mouton.

Keraf, Gorys. 1994. Diksi dan Gaya Bahasa. Jakarta: Gramedia Putaka Utama.

Kridalaksana, Harimurti. 2007. Pembentukan Kata dalam Bahasa Indonesia. Jakarta: Gramedia Pustaka Utama.

. 2008. Kamus Linguistik. Jakarta: Gramedia.

Pateda, Mansoer. 2001. Semantik Leksikal. Jakarta: PT. Rineka Cipta.

Ramlan, M. 1995. Morfologi Suatu Tinjauan Deskriptif. Yogyakarta:Pustaka

Rosdiana, A.R. 2011. Kamus Kebidanan. Bandung: Pramedia.

Sudaryanto. 1986. Metode Linguistik: Bagian Pertama Ke Arah Memahami Metode Linguistik. Yogyakarta: Gajah Mada University Press.

1988. Metode Linguistik Ke Arah Memahami Metode Linguistik. Yogyakarta: Gajah Mada University Press.

Suwito. 1985. Pengantar awal sosiolinguistik: teori dan problema. Surakarta: henary offset.

Wiratami, Rety. 2011. Penggunaan Register dalam Diktat Anatomi. Skripsi. Surabaya: Fakultas Ilmu Budaya. Universitas Airlangga. 